\title{
Designing Web-Based DISC Psychology Personality Analysis Tests
}

\author{
Daniel Aditama Somatdie \\ Information System Departement, Soegijapranata Catholic University \\ danieladitama11@gmail.com \\ Erdhi Widyarto \\ Information System Departement, Soegijapranata Catholic University \\ erdhi@unika.ac.id \\ Alb. Dwiyoga Widiantoro \\ Information System Departement, Soegijapranata Catholic University \\ yoga@unika.ac.id
}

\begin{abstract}
Using a manual system in the companies or organizations today, has many disadvantages like inefficient, wasting time, require a lot of costs, and make work difficult. By integrating a DISC personality analytical psychological test with information system, the tests are carried out with computers initially using paper, so it more economical for using less paper. More than that, the test results are done automatically check by the computer, no need to manually check by the psychologist. In addition to being effective in examining, the validation of examinations is very high because it can recover human errors.
\end{abstract}

Keywords - online test, phycology test, DISC assessment online test, information system, computerized based test

\section{INTRODUCTION}

Psychology test or psychological test is a tool used to find out a person's condition [1]. This psychological test is used to measure the functions of cognitive and emotional abilities such as intelligence, interests and talents, to the personality of the person [2]. The psychological test method is a psychology research tool that is important for the ability to be tested, for the example is attitudes, talents, personality traits, and interests [3]. Personality is all kinds of varied behaviors carried out by individuals who are regulated by order and harmonization [4]. To find an individual personality, the individual can take the personality psychology test. Personality psychology tests are professional psychology proficiency which include administration, assessment, and interpretation of the support of calculating traits and styles[5].

One of the personality psychology tests is the DISC test. DISC theory is a psychological theory used to determine people's personalities based on people's emotional behavior based on their environment. DISC is divided into four personalities, there are: Dominance (D), Influence (I), Steadiness (S), and Compliance (C) [6]. The psychological test of DISC personality analysis is done on paper. Individuals who will be tested will answer on paper and then processed manually and calculated manually. But this system is less efficient and takes a lot of time.

With the internet technology, which one is web-base, communication and information services can be done easily and efficiently [7]. To use technology in an organization must have an information system. An information system in an organization provides processes and information that is useful for members and clients of the organization. With this information system, they can operate more effectively [8]. Moreover, the content validity of technology-based test examinations is higher too. Content validity is a benchmark for reflecting the content domain as expected [9]. With technology, the goal is to reduce human error in examination, so the test results 
more valid. Utilization of computerized technology for DISC personality analysis psychological test from previously done paper-based test is an interesting part to be explored. Because, with the many advantages of using computers for psychological tests of DISC personality analysis can develop the organization and improve work effectiveness.

\section{LITERATUR REVIEW}

\section{A. Test}

According to Freidenberg in 1995, test is a type of assessment that had specific procedures for sending information and converting information to numerical forms. The Personality Analysis Test is a Typical performance test, a test used to measure typical performance. This test is usually used for typical behavior, thinking habits, and feelings[10].

\section{B. Phycological Test}

Psychological test is a tool that are used as benchmarks for psychological aspects of the individual. Psychological test is containing interview questions that are packaged in written form [2].

\section{DISC Theory}

DISC theory was first put forward by William Moulton Marston, namely the expression of emotional behavior divided into four types of individuals when interacting with their environment: Dominance (D), Influence (I), Steadiness (S), and Compliance (C). Marston calls that four "primary emotions"[11]. DISC personality analysis test has been used by more than 50 million test users and published in books that have been translated in 35 languages [12]. Personalitybased DISC tests are used to classify potential members into a group, and measure productivity from members. Beside that it is also useful for psychometric measurement, leadership, and activeness in the organization [13]. Although valid, the DISC test can change because the emotional experience of an individual tends to change rather than be eternal [14].

\section{Computer Assisted Test}

Computer Assisted Test (CAT) is a test performed with a computer. Computers can be used in various uses as test media. Starting from the simplest, which is used to display exam questions, check test results, and give test scores[15]. So, the efficiency and validity of the answer check will increase [16].

\section{E. Online DISC Personality Analysis Test}

The web-based DISC personality analysis psychological test application is used to classify personality types based on test results. In an application test experiment to select KKL participants at Amikom Purwokerto, from the experiment, 59\% of the 6 questions through the questionnaire were approved by the respondents [17].

\section{F. Hypertext Preprocessor (PHP)}

Hypertext Preprocessor (PHP) is a simple and powerful programming language designed to create HTML content. PHP can be run on many operating systems such as Linux, Solaris, FreeBSD, MacOS X and Windows. In addition, various web servers can be used, such as Apache, Microsoft IIS, and Netscape [18]. PHP can be obtained free of charge. To download PHP just by visiting the site www.php.net and applying it to the PHP editor [19].

\section{G. Waterfall Method}

Waterfall method is a method used for learning in developing a software [20]. First, the waterfall method was published by Walter Royce in 1970 [21]. The method of work of this method is that the conditions of the ongoing stage must be completed before proceeding to the next stage [22].

\section{RESEARCH METHODOLOGY}

The application development process used in this study uses the waterfall model. The application development began with collecting data through interviews with the Center for Applied Psychology (PPT) at Unika Soegijapranata. In addition to interviews, data searching is also done by looking for sources in books, journals, and 
other media that can be related to research. Continued for making application concepts. Making application concepts includes application flow, mockup, database design, and determining user roles. Continued with, making the program. The programming is done with the programming language PHP and Bootstrap Framework using the Visual Studio Code editor. The database is created using phpMyAdmin on a MySQL basis. After the program is finished, the application is tested. If the application is appropriate, the application will be implemented to the client and perform maintenance. After that, the application will be used as a research medium.

In this study, the object of research was people, with the population being psychologists, staff, and participants from the Applied Psychology Unika Soegijapranata and samples used by 30 students. The source of the primary data of this study came from questionnaires given to 30 respondents and interviews with psychologists and PPT staff and secondary data sources of this study came from journals, articles, and literature regarding the psychological test of DISC.

\section{RESULTS AND DISCUSSION}

The results of this application design are called online DISC personality analysis psychological tests. This application consists of 3 user roles, namely participants, psychologists, and staff. Figure 1 is the flow diagram of the application.

The use case of the DISC personality analysis psychological test application is as Figure 2.

Designing databases using Entity Relational Diagrams (ERD) from DISC personality analysis psychological test applications is as Figure 3.

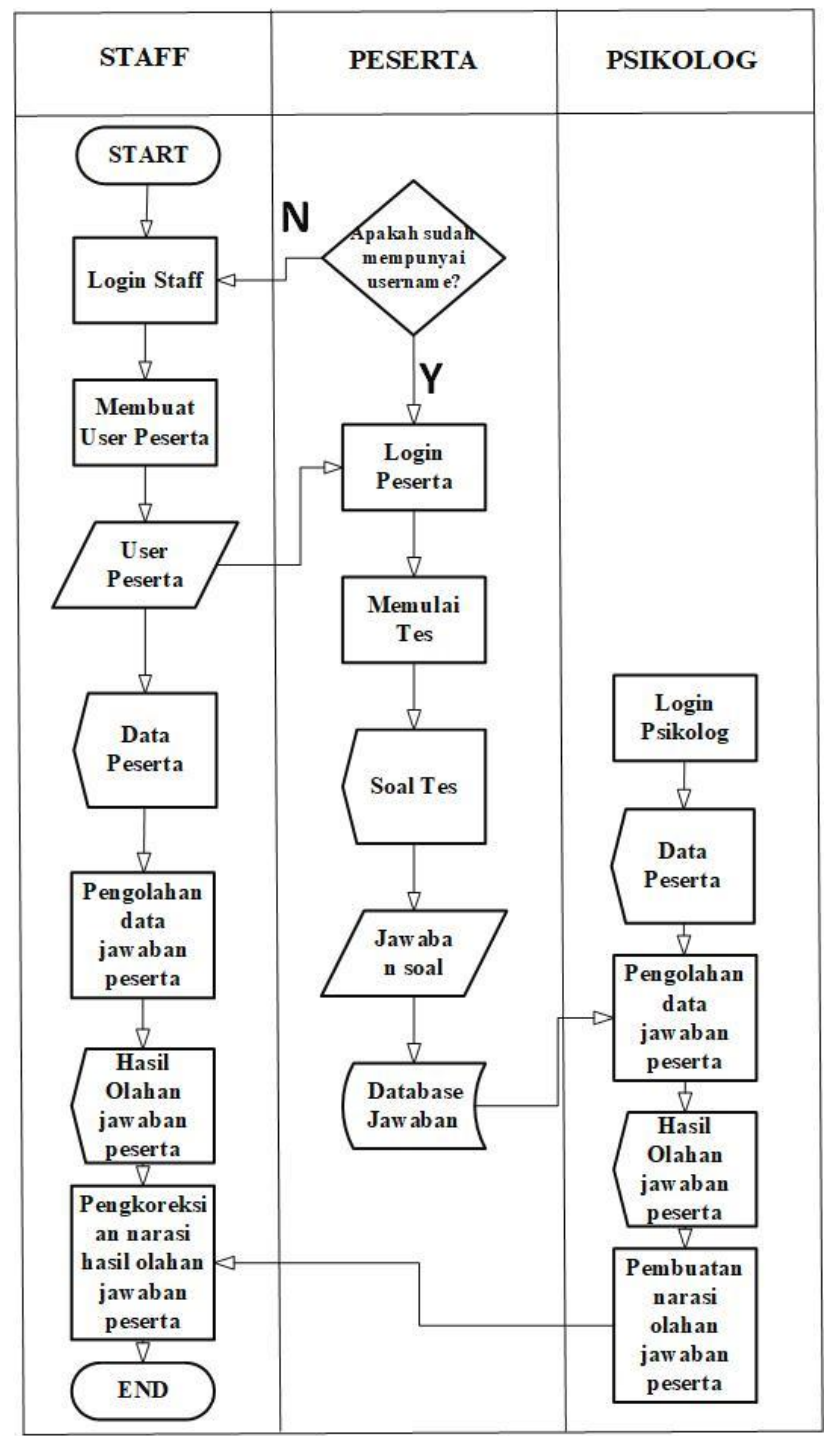

Figure 1. Application Workflow

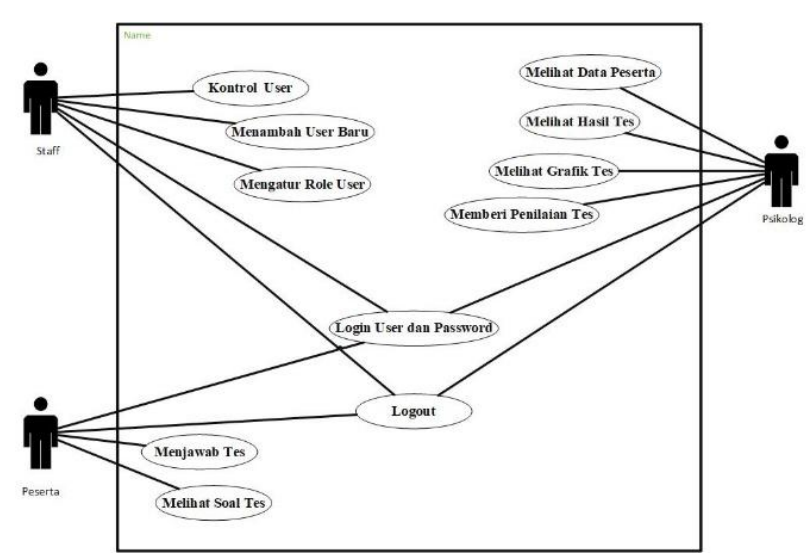

Figure 2. Application Use Case 


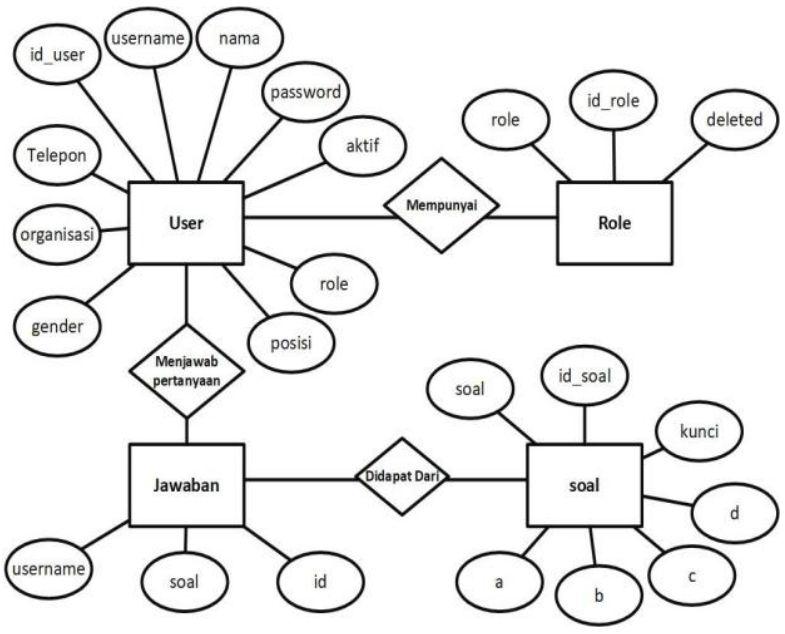

Figure 3. Application ERD
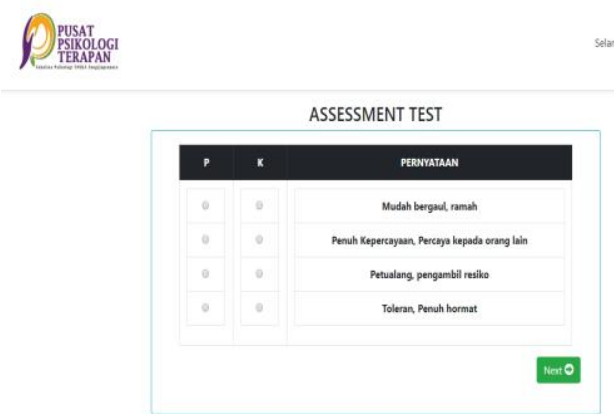

Figure 4. Display of Participant Question.

Psychologists have the task of giving conclusions to answers the results that have been processed by the computer. The computer processing results are calculating the accumulated answers of participants, calculating the graph automatically, and showing conclusions of the behavior and work field that is suitable for participants.

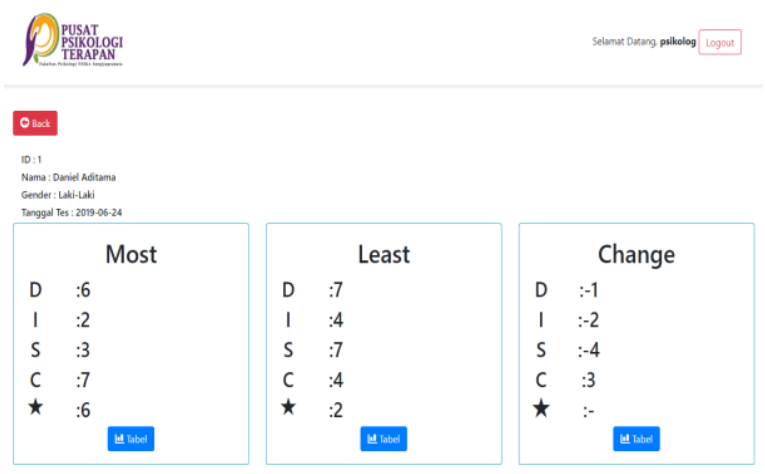

Figure 5. Display of Answer Accumulation

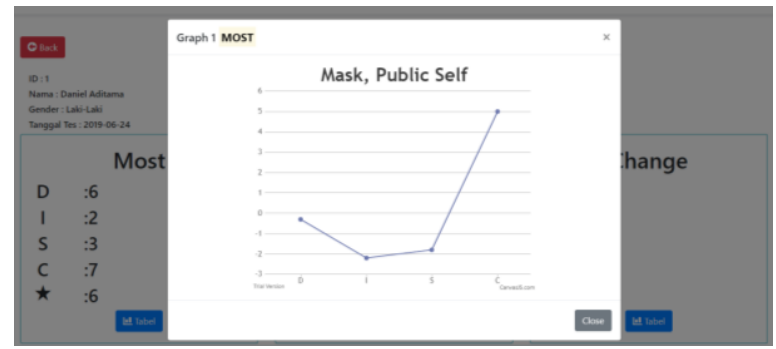

Figure 6. Display of DISC Graph

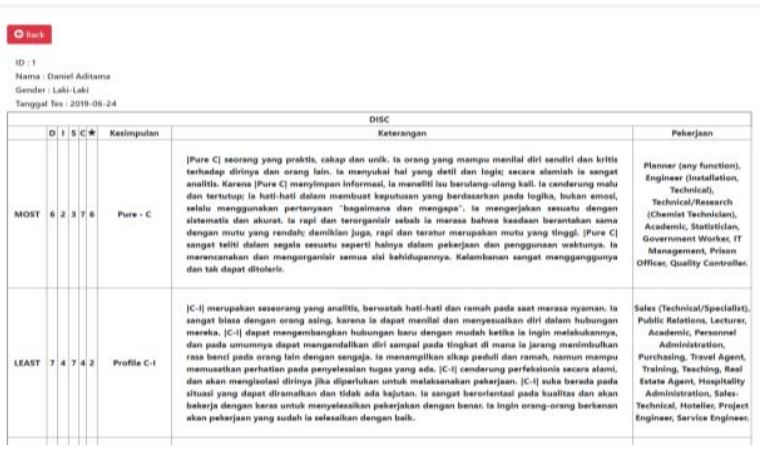

Figure 7. Display of Participant Conclusions

Staff role is to add new users. Staff can also see user management. User management is used to view active users, edit user data, and delete users.

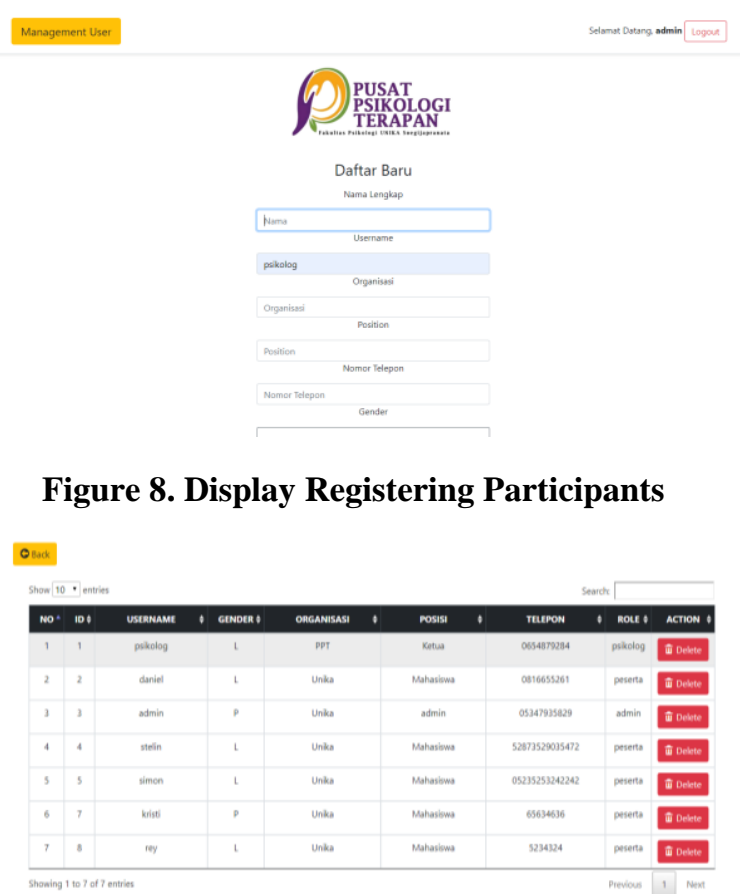

Figure 9. Display User Management

The questionnaire consists of 2 sessions, the respondents' demographic questions and application review questions 


\section{A. Demographics of Respondents}

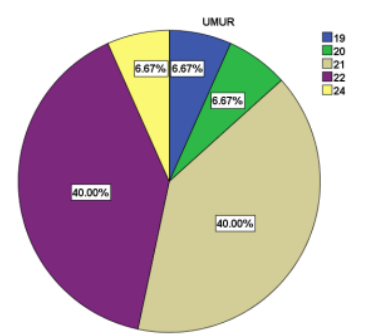

Figure 10. Age of Respondents

From 30 respondents, the majority of respondents were 20 and 21 years old as much as $40 \%$. While respondents aged 19,22 , and 24 years were $6.67 \%$.

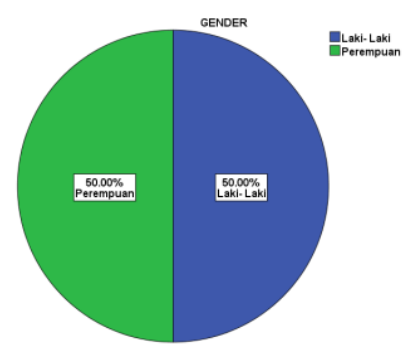

Figure 11. Respondent Gender Diagram

From 30 respondents, balanced sex data was taken. That is $50 \%$ male and $50 \%$ female.

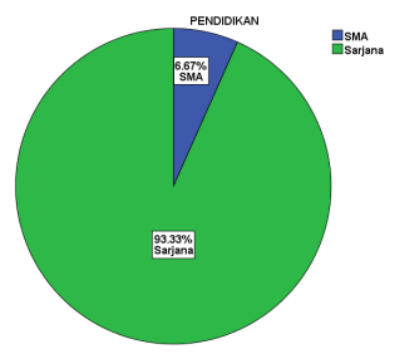

Figure 12. Respondents' Educational Diagram

Education taken by respondents at this time, as many as $93.33 \%$ of the 30 respondents were pursuing a degree. While $6.67 \%$ were taking high school.

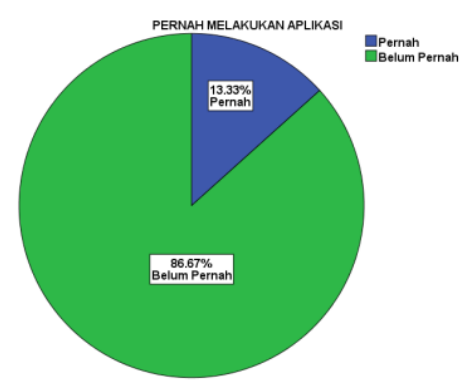

Figure 13. Ever Using Respondent's Application Diagram
As many as $86.67 \%$ of the 30 respondents had never done DISC personality analysis psychological tests. While respondents who had taken the DISC personality analysis test were $13.33 \%$.

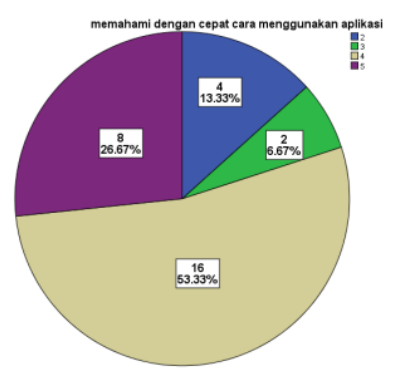

Figure 14. Application Usage Understanding Diagram

There are 16 respondents or $53.33 \%$ agree that understand how to use the application quickly. While 8 people or $26.67 \%$ answered strongly agree, 4 people or $13.33 \%$ answered that they did not understand quickly using the application and 2 people or $6.67 \%$ were neutral.

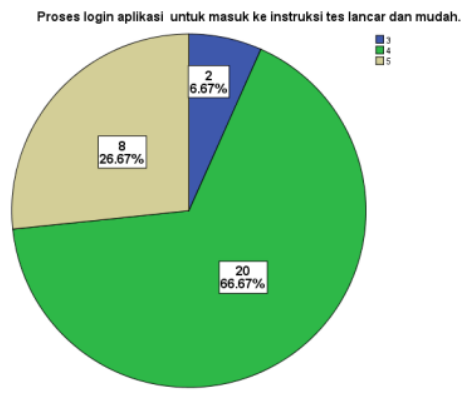

Figure 15. Convenience and Activity Diagrams Application Login

A total of 20 respondents or $66.67 \%$ agreed that the login process was easy and smooth. While as many as 8 respondents or $26.67 \%$ strongly agree if the login process is smooth and easy and 2 respondents or $6.67 \%$ disagree if the login process is smooth and easy.

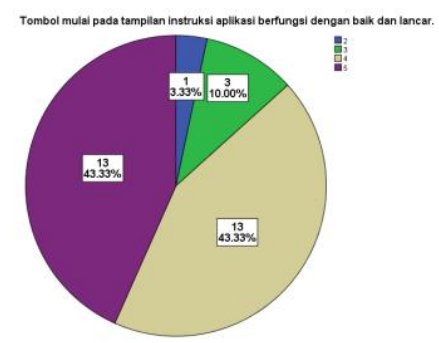

Figure 16. Smooth Start Application Application Button Diagram 
Both respondents who agreed and strongly agreed to have a total of 13 respondents or $43.33 \%$. While those who disagree are only 1 person or $3.33 \%$ and 3 more or $10 \%$ are neutral.

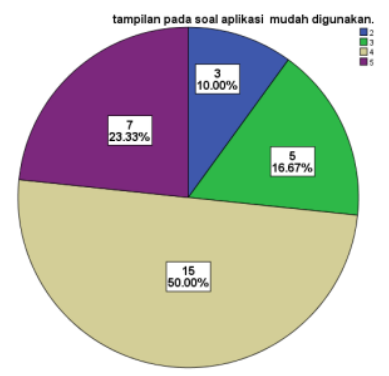

Figure 17. Ease Diagram for Using the Start Button in the Application Problem

A total of 15 respondents or as many as $50 \%$ agreed that the button starts in the matter of easy application to use. While 7 respondents or $23.33 \%$ felt strongly agree, 5 respondents or $16.67 \%$ Neutral, and 3 respondents or $10 \%$ did not agree.

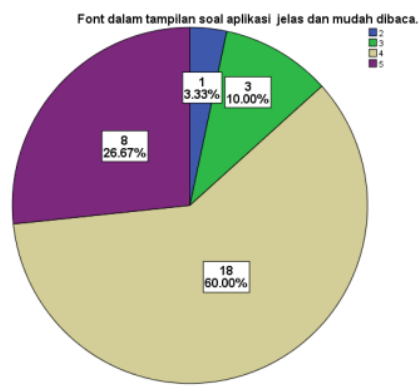

Figure 18. Easy to read fonts in question view

Respondents who agreed to feel easy to read the font in the display question as many as 18 respondents or $60 \%$. While 8 respondents or $26.67 \%$ strongly agreed, 3 respondents or $10 \%$ were neutral and 1 respondent or as much as $3.33 \%$ did not agree.

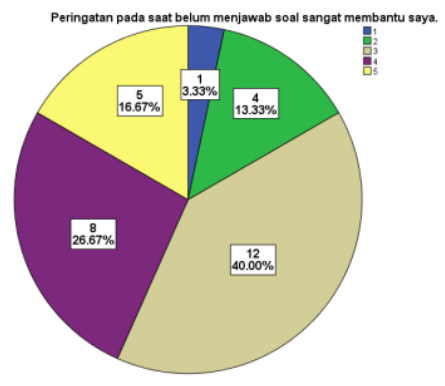

Figure 19. The Convenient Diagram answers the question with the warning feature
12 respondents or $40 \%$ were neutral that the warning when not answering the question was very helpful. The remaining 8 respondents or $26.67 \%$ agree, 5 respondents or $16.67 \%$ strongly agree, 4 respondents or $13.33 \%$ disagree and 1 respondent strongly disagrees or as much as $3.33 \%$.

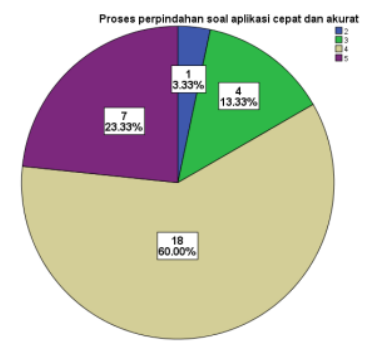

Figure 20. Convenience Diagrams in the process of transferring applications

Respondents who agreed that the process of moving the application questions quickly and accurately was 18 respondents or $60 \%$. While 7 respondents or $23.33 \%$ strongly agreed. A total of 4 respondents or $13.33 \%$ were neutral, and 1 respondent or $3.33 \%$ did not agree

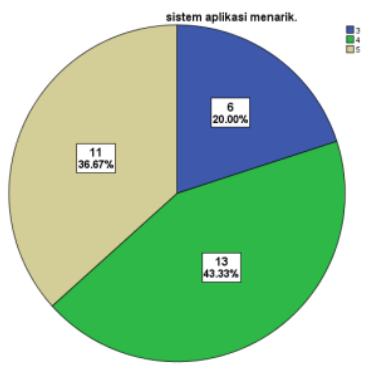

Figure 21. Application Drawing Diagram

There are 13 respondents or $43.33 \%$ agree that the application system is interesting. While 11 respondents or $36.67 \%$ strongly agreed and 6 respondents or $20 \%$ were neutral.

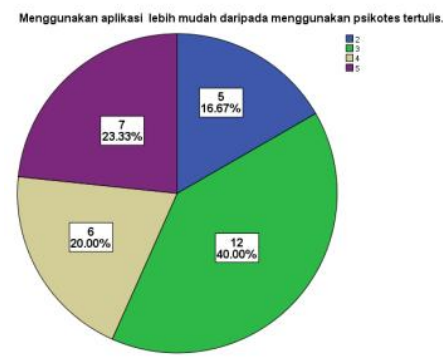

Figure 22. Application Usage Chart is easier than conventional 
Twelve respondents or $40 \%$ were neutral in feeling that using the application was more convenient than the written psychological test. While as many as 6 respondents or $20 \%$ agreed, 7 respondents or $23.33 \%$ strongly agreed, and 5 people or $16.67 \%$ did not agree.

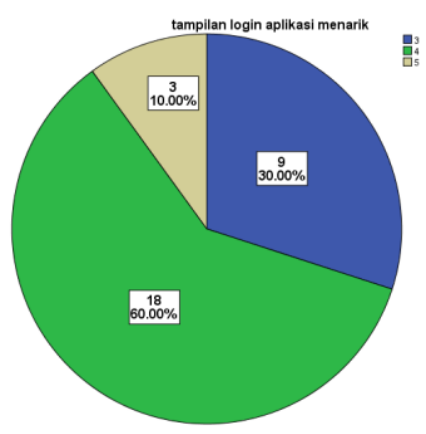

Figure 23 Convenience Diagrams in the process of transferring applications

In attracting the login screen, 18 people or $60 \%$ agreed. While 9 respondents or $30 \%$ were neutral and 3 people or $10 \%$ strongly agreed.

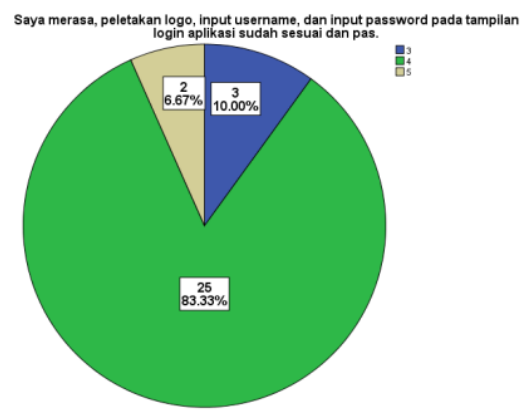

Figure 24 Comfort Diagram Layout login View

A total of 25 respondents or $83.33 \%$ agreed that the layout of the login display was appropriate and appropriate. While 3 respondents or $10 \%$ were neutral and 2 respondents or $6.67 \%$ strongly agreed.

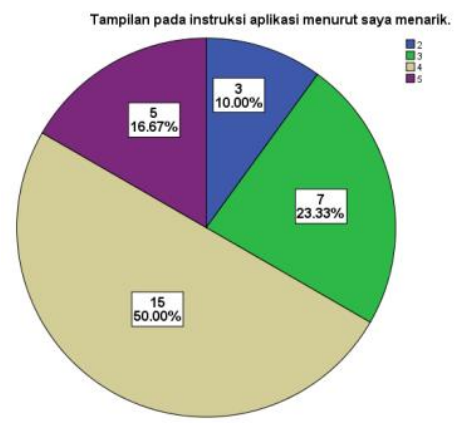

Figure 25. Drawn diagram of instruction display
15 respondents or $50 \%$ agreed if the instruction display was interesting. While 7 respondents or $23.33 \%$ were neutral, 6 respondents or $16.67 \%$ strongly agreed, and 3 respondents or $10 \%$ did not agree.

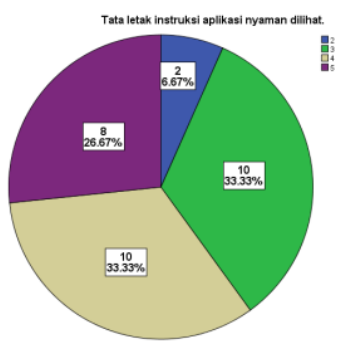

Figure 26. Comfort Diagram Layout of instruction display

Both respondents agreed and neutral each amounted to 10 respondents or as much as $33.33 \%$. While as many as 8 respondents or $26.67 \%$ strongly agree, and 2 respondents or $6.67 \%$ disagree.

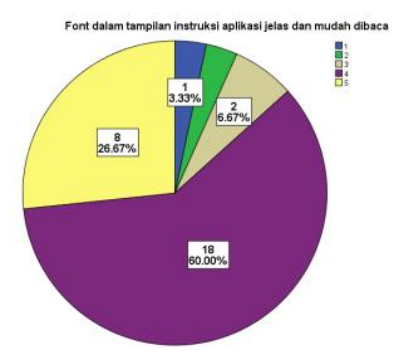

Figure 27. Comfort diagram in reading the instruction display font

Sejumlah 18 responden atau 60\% setuju bahwa font di tampilan instruksi jelas dan mudah dibaca. Sementara 8 responden atau $26,67 \%$ sangat setuju, 2 responden atau $6,67 \%$ netral dan masing-masing 1 responden atau 3,33\% tidak setuju dan sangat tidak setuju.

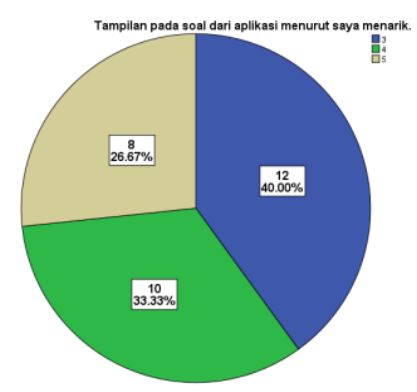

Figure 28. Drawn diagram of the display in the application 
Respondents who feel neutral if the display of interesting questions as many as 12 respondents or $40 \%$. Respondents who agreed were 10 respondents or $33.33 \%$ and strongly agreed with 8 respondents or $26.67 \%$.

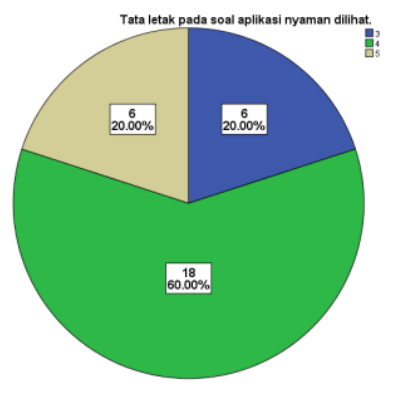

Figure 29. The layout comfort of the application questions

A total of 18 respondents or $60 \%$ agreed that the layout of the display about the application is comfortable to see. While each 6 or $20 \%$ of respondents were very agree and neutral.

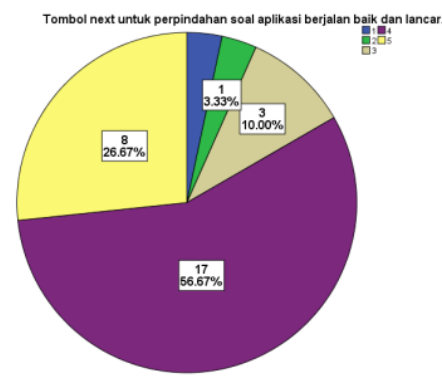

Figure 30. The smoothness of the next button to move the application problem

A total of 17 respondents or $56.67 \%$ agreed if the next button for switching about the application went well and smoothly. While 8 respondents or $26.67 \%$ strongly agreed, 3 respondents or $10 \%$ were neutral and each 1 respondent or $3.33 \%$ did not agree and strongly disagree.

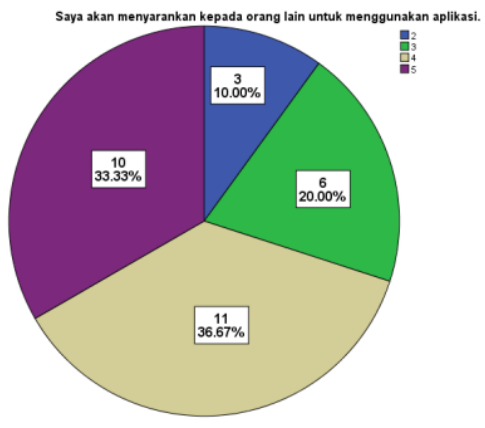

Figure 31. Intention Diagram Suggesting Applications to Others
11 respondents or $36.67 \%$ suggested applications to others to use the application. While 10 respondents or $33.33 \%$ strongly recommend, 6 respondents or $20 \%$ neutral and 3 respondents or $10 \%$ do not recommend.

\section{REFERENCES}

[1] C. Suwartono, "Alat Tes Psikologi Konteks Indonesia: Tantangan Psikologi di Era MEA," J. Psikol. Ulayat, vol. 3, no. 1, p. 1, 2017.

[2] I. M. Kabinani, S. Rostianingsih, and L. P. Dewi, "KARIR DAN TES MINAT JABATAN PADA PUSAT KARIR UNIVERSITAS."

[3] Y. Jahja, Psikologi Perkembangan, Pertama. Jakarta: Kharima Putra Utama, 2011.

[4] C. S. Hall and G. Lindzey, Psikologi Kepribadian 1 TEORI-TEORI PSIKODINAMIK (KLINIS). Yogyakarta: Kanisius, 1993.

[5] American Psychological Association (APA), "Personality Assessment." [Online]. Available: https://www.apa.org/ed/graduate/speci alize/personality. [Accessed: 26-Jun2019].

[6] C. K. E. Goni, H. Opod, and L. David, "Gambaran kepribadian berdasarkan tes Disc mahasiswa Fakultas Kedokteran Universitas Sam Ratulangi Manado semester 1 tahun 2016," vol. 4, 2016.

[7] K. Hernawati, "Evaluasi dan Penilaian Interaktif Berbasis Web," 2006.

[8] D. Avison and G. Fitzgerald, Information System Development, 4th ed. Singapore: McGraw-Hill Education (UK), 2006.

[9] I. W. Santyasa, "ANALISIS BUTIR DAN KONSISTENSI INTERNAL TES," pp. 1-12, 2005.

[10] Supratiknya, Penilaian Hasil Belajar dengan Teknik Nontes, vol. 28, no. 12. 2006.

[11] Wiley, "Research Report for Adaptive Testing Assessment," John Wiley Sons, Inc., 2018. 
[12] C. S. Jones and N. T. Hartley, "Comparing Correlations Between Four-Quadrant And Five-Factor Personality Assessments," Am. J. Bus. Educ., vol. 6, no. 4, p. 459, 2016.

[13] C. A. Bhardwaj, M. Mishra, and S. Hemalatha, "An Automated Compatibility Prediction Engine using DISC Theory Based Classification and Neural Networks," arXiv Prepr. arXiv1709.00539, 2017.

[14] I. Publishing, "DiSC® Classic and Models of Personality," 1996.

[15] F. Putrawansyah, "Aplikasi Computer Assisted Test (CAT) Pada Penerimaan Mahasiswa Baru Sekolah Tinggi Teknologi Pagar Alam (STTP)," vol. 1, no. 1, pp. 1-8, 2017.

[16] G. Lippey and F. B. Baker, Computerassisted Test Construction. New Jersey: Educational Technology, 1974.

[17] I. Santiko, A. Prasetyo, and P. N. Sukisno, "Implementation of Psychotest System Application Selection of KKL STMIK Participants in Purwokerto Amikom Using DISC ( Dominance-Influence-SteadinessCompliance )," vol. 4, no. 1, 2019.
[18] B. K. Rasmus Lerdorf, Kevin Tatroe, Programming PHP, First Edit. Sebastopol: O'Reilly Media, Inc., 2002.

[19] L. Atkinson, Core PHP Programming, Second Edi. New Jersey, 2001.

[20] M. G. Limaye, Software Testing, First Repr. New Delhi: Tata Mc-Graw Hill, 2009.

[21] K. Petersen, C. Wohlin, and D. Baca, "The Waterfall Model in Large-Scale," Prod. Softw. Process Improv. 10th Int. Conf. PROFES 2009, pp. 386-400, 2009.

[22] S. Balaji and M. Sundararajan Murugaiyan, "Waterfall Vs V-Model Vs Agile: A Comparative Study On SDLC," Int. J. Inf. Technol. Bus. Manag., vol. 292, no. 1, pp. 26-30, 2012. 